DOI: https://doi.org/10.24127/ajpm.v9i4.2979

\title{
STUDENT TEAMS ACHIEVEMENT DIVISIONS (STAD) DENGAN PENDEKATAN REALISTIC MATHEMATICS EDUCATION (RME) TERHADAP KEMAMPUAN PEMAHAMAN MATEMATIS
}

\author{
Sufri Mashuri ${ }^{*}$, Jahring ${ }^{2}$, Nasruddin ${ }^{3}$ \\ ${ }^{*}, 2,3$ Pendidikan Matematika, Universitas Sembilanbelas November Kolaka, Indonesia \\ ${ }^{*}$ Corresponding author. Jl. Pemuda No.339 Kolaka, Sulawesi Tenggara, Indonesia \\ E-mail: $\quad$ sufri13@gmail.com ${ }^{\left.{ }^{*}\right)}$ \\ jahring.usn@ gmail.com ${ }^{2)}$ \\ nash.matematika@gmail.com $^{3)}$
}

Received 21 July 2020; Received in revised form 07 September 2020; Accepted 17 September 2020

\begin{abstract}
Abstrak
Penelitian ini bertujuan untuk mengetahui efektifitas model pembelajaran kooperatif tipe Student Teams Achievement Divisions (STAD) dengan Pendekatan Realistic Mathematics Education (RME) dalam meningkatkan kemampuan pemahaman matematis siswa kelas VIII MTs Nurul Yaqin Dawi-dawi. Penelitian ini merupakan jenis penelitian eksperimen dengan melibatkan seluruh siswa kelas VIII sebagai populasi penelitian. Hasil penelitian secara empiris menunjukkan bahwa: (1) peningkatan kemampuan pemahaman matematis siswa pada kelas eksperimen yang terdiri dari 26 siswa menunjukkan bahwa nilai minimum 0,14 , nilai maksimum 1,00 , rata- rata 0,670 , standar deviasi 0,206 , dan varians 0,$042 ;(2)$ peningkatan kemampuan pemahaman matematis siswa pada kelas Kontrol yang terdiri dari 29 siswa menunjukkan nilai minimum 0,25 , nilai maksimum 0,86 , rata- rata 0,5449 , standar deviasi 0,200 , dan varians 0,040; dan (3) melalui analisis lembar observasi aktivitas guru dan siswa pada kedua kelas penelitian telah menunjukkan kriteria aktif dengan nilai rata- rata persentase sebesar 75\% - 90\%. Hasil penelitian secara inferensial dengan menggunakan uji- $t$ telah diperoleh nilai $t_{\text {hitung }}(2,287)>t_{\text {tabel }}$ (2,006) yang menunjukkan bahwa $H_{0}$ ditolak dan $H_{1}$ diterima, secara inferensial ini berarti bahwa terdapat perbedaan yang signifikan antara kemampuan pemahaman matematis siswa pada kelas eksperimen dan kelas kontrol. Dari hasil penelitian tersebut dapat disimpulkan bahwa kemampuan pemahaman matematis siswa dengan penerapan model pembelajaran kooperatif tipe STAD dengan pendekatan RME efektif dalam meningkatkan pemahaman matematis siswa.
\end{abstract}

Kata kunci: efektifitas; RME; STAD.

\begin{abstract}
This study aims to determine the effectiveness of the Student Teams Achievement Divisions (STAD) cooperative learning model with a Realistic Mathematical Education (RME) in improving the mathematical understanding ability of eighth grade students of MTs Nurul Yaqin Dawi-Dawi. This research is a type of experimental research involving all students of class VIII as the study population. The results of the empirical study show that: (1) improvement in the ability of mathematical in the experimental class consisting of 26 students shows that the minimum value is 0.14 , the maximum value 1.00, the average 0.670, standard deviation of 0.206, and variance of 0.042; (2) improvement of students' mathematical understanding abilities in the Control class consisting of 29 students showed a minimum value of 0.25, a maximum value of 0.86, an average of 0.5449, a standard deviation of 0.200, and a variance of 0.040; and (3) through analysis of observation sheets of teacher and student activities in both classes of research have shown active criteria with an average percentage of $75 \%-90 \%$. The results of inferential research using the $t$-test has obtained the value of $t_{\text {hitung }}(2.287)>t_{\text {tabel }}(2.006)$ which shows that $H_{0}$ is rejected and $H_{1}$ is accepted, this inferential means that there is a significant difference between students' mathematical understanding abilities in the experimental class and control class. From these results it can be concluded that the students' mathematical understanding ability by applying the STAD type cooperative learning model with the RME is effective in improving the mathematical understanding.
\end{abstract}

Keywords: effectiveness; RME; STAD.

This is an open access article under the Creative Commons Attribution 4.0 International License 
DOI: https://doi.org/10.24127/ajpm.v9i4.2979

\section{PENDAHULUAN}

$\begin{array}{cccc} & \text { Pendidikan } & \text { mempunyai } & \text { peran } \\ \text { yang } & \text { sangat } & \text { strategis } & \text { dalam }\end{array}$
meningkatkan kualitas sumber daya manusia dan upaya mewujudkan citacita bangsa Indonesia dalam mewujudkan kesejahteraan umum dan mencerdaskan kehidupan bangsa. Tidak hanya itu, pendidikan juga memberikan kontribusi yang besar dalam perkembangan ilmu pengetahuan dan wawasan kepada mereka yang mengemban dunia pendidikan, (Nasruddin et al., 2020). Salah satu faktor utama untuk meningkatkan mutu pendidikan adalah mutu sumber daya manusi dalam ini adalah guru. Langkah awal yang harus diperhatikan oleh seorang guru dalam melaksakan pembelajaran adalah perencanaan pembelajaran yang matang baik pembelajaran yang dilaksanakan di kelas maupun di luar kelas, (Jailani et al., 2018; Mariamah, 2014).

Matematika sebagai salah satu mata pelajaran dasar pada setiap jenjang pendidikan formal, mempunyai peran yang sangat penting dalam dunia pendidikan. Sebab pelajaran matematika sangat berkaitan dengan kondisi kehidupan kita sehari-hari, (Jahring, 2020). Selain itu, pembelajaran matematika memiliki peran penting yang menjadi sarana dalam pemecahan masalah kehidupan, dan befungsi dalam mengembangkan daya nalar kemampuan berpikir, (Suandito, 2017).

Pemahaman terhadap konsepkonsep matematika merupakan dasar bagi siswa untuk belajar matematika secara bermakna dan mendalam, (Nasruddin et al., 2019; Saputra \& Sukariasih, 2019). Siswa belajar melalui keterlibatan aktif dengan konsep dan prinsip sedangkan guru mendorong siswa untuk mendapat pengalaman dengan melakukan berbagai kegiatan yang dapat memungkinkan mereka menemukan kemampuan dasar dan konsep sendiri, (Djidu \& Jailani, 2017; Sejati et al., 2017).

Berdasarkan hasil wawancara dengan guru matematika di MTs Nurul Yaqin Dawi - Dawi, diperoleh realita bahwa kemampuan pemahaman matematis siswa kelas VIII masih tergolong rendah. Hal ini ditandai jika guru memberikan soal yang modelnya sedikit berbeda dari contoh yang telah diberikan sebelumnya, maka sebagian besar siswa mengalami kesulitan dalam menyelesaikan soal-soal tersebut. Jika guru menanyakan kembali mengenai konsep materi pelajaran matematika pada pertemuan sebelumnya, maka sebagian besar siswa tidak dapat menjawabnya.

Bercermin dari masalah di atas, diperlukan usaha guru agar siswa belajar secara aktif sehingga siswa mempunyai kemampuan tersendiri dalam memahami konsep serta dalam mencapai tujuan pembelajaran. Langkah awal yang harus dilakukan guru adalah dengan mengetahui gaya belajar siswa, karena dengan informasi awal tentang gaya belajar, guru dapat menentukan model pembelajaran yang tepat, (Jahring \& Chairuddin, 2019). Salah satu usaha guru dalam meningkatkan kemampuan pemahaman matematis siswa adalah dengan menggunakan model pembelajaran kooperatif. Sebab pembelajaran kooperatif dapat membangun semangat siswa dalam proses pembelajaran.

Model pembelajaran yang tepat dalam meningkatkan kemampuan pemahaman matematis siswa adalah model pembelajaran kooperatif tipe STAD dengan pendekatan RME. Berdasarkan penelitian yang dilakukan 
oleh (Surtiani \& Syahputra, 2016) bahwa dengan menerapkan model pembelajaran kooperatif tipe STAD dapat meningkatkan pemahaman konsep matematika siswa. Selain itu, pembelajaran dengan pendekatan RME lebih efektif dibandingkan model pembelajaran konvensional, (Yulianty, 2019).

Model Pembelajaran kooperatif merupakan salah satu bentuk pembelajaran yang berdasarkan falsafah konstruktivis, yakni melatih cara berpikir dan bernalar dalam menarik kesimpulan, (Djidu \& Jailani, 2017; Mariamah, 2014; Nasruddin \& Abidin, 2017).

Berdasarkan uraian tersebut, maka dilakukan penelitian penerapan model pembelajaran kooperatif tipe STAD dengan pendekatan RME dalam meningkatkan kemampuan pemahaman matematis siswa. Penelitian ini bertujuan untuk melihat efektifitas model pembelajaran kooperatif tipe STAD dengan pendekatan RME dalam meningkatkan kemampuan pemahaman matematis siswa kelas VIII MTs Nurul Yaqin Dawi-Dawi.

\section{METODE PENELITIAN}

Jenis penelitian ini adalah penelitian eksperimen dengan membandingkan dua model pembelajaran berbeda yang diterapkan pada dua kelas yakni kelas eksperimen dan kelas kontrol. Penelitian ini dilakukan di kelas VIII MTs Nurul Yaqin Dawi-dawi yang beralamat di Kelurahan Dawi-Dawi Kecamatan Pomalaa Kabupaten Kolaka Sulawesi Tenggara.

Desain penelitian yang digunakan adalah Quasi Experimen Design dengan rancangan Noneqivalent Control Group Design. Rancangan desain penelitian tersebut disajikan pada Tabel 1.
Tabel 1. Desain penelitian.

\begin{tabular}{cccc}
\hline Kelompok & Evaluasi & Perlakuan & Evaluasi \\
\hline KE & Pretest & X & Posttest \\
KK & Pretest & Y & Posttest
\end{tabular}

Keterangan:

KE : Kelas Eksperimen

KK : Kelas Kontrol

$\mathrm{X}$ : Penerapan model pembelajaran kooperatif tipe STAD dengan pendekatan RME

$\mathrm{Y}$ : Pembelajan konvensional

Populasi dalam penelitian ini adalah seluruh siswa kelas VIII MTs Nurul Yaqin Dawi-Dawi yang terdiri dari dua kelas paralel dengan jumlah siswa 55 orang. Pemilihan sampel dalam penelitian ini menggunakan teknik Totally Sampling (Sampel jenuh), yakni semua anggota populasi digunakan sebagai sampel. Adapun sampel dalam penelitian ini adalah seluruh siswa kelas VIII MTs Nurul Yaqin Dawi-dawi yang berjumlah 55 orang meliputi kelas VIII A dengan jumlah siswa 26 orang sebagai kelas ekperimen dan kelas VIII B dengan jumlah siswa 29 orang sebagai kelas kontrol.

Instrumen dalam penelitian ini adalah soal tes kemampuan pemahaman konsep dalam bentuk uraian yang diberikan pada saat pelaksanaan pretest dan posttest. Instrumen tes ini dilengkapi dengan pedoman penskoran kemampuan pemahaman matematis yang terdiri dari tiga indikator, yakni Translasi, Intrapolasi, dan Ekstrapolasi.

Data tentang kemampuan pemahaman konsep matematis siswa dalam penelitian ini dianalisis melalui dua tahapan, yaitu analisis deskriptif meliputi: (1) Mean; (2) Varians; dan (3) Standar Deviasi, kemudian kemampuan pemahaman matematis siswa dianalisis berdasarkan indikator kemampuan pemahaman matematis serta analisis 
inferensial, yaitu uji hipotesis dengan kriteria tolak $H_{0}$ jika nilai thitung $>t_{\text {tabel }}$ pada taraf signifikansi $\alpha=0,05$.

\section{HASIL DAN PEMBAHASAN}

Hasil dalam penelitian ini mencakup dua hal, yakni analisis deskriptif dan analisis inferensial. Hasil analisis deskriptif terhadap kemampuan pemahaman matematis siswa baik di kelas eksperimen maupun di kelas kontrol dapat dilihat pada Tabel 2.

Tabel 2. Hasil analisis deskriptif kemampuan pemahaman konsep matematis siswa.

\begin{tabular}{ccccccc}
\hline \multirow{2}{*}{ Statistik } & \multicolumn{3}{c}{ Eksperimen } & \multicolumn{3}{c}{ Kontrol } \\
\cline { 2 - 7 } & Pretest & Posttest & N-Gain & Pretest & Posttest & N-Gain \\
\hline N & 26 & 26 & 26 & 29 & 29 & 29 \\
Mean & 53,365 & 84,134 & 0,6703 & 52,083 & 77,672 & 0,5449 \\
Standar Deviasi & 9,539 & 10,098 & 0,206 & 9,579 & 11,494 & 0,2002 \\
Varians & 90,999 & 101,97 & 0,042 & 91,766 & 132,11 & 0,040 \\
Minimum & 41,67 & 62,5 & 0,14 & 37,5 & 57,5 & 0,25 \\
Maksimum & 75,00 & 100 & 1,00 & 70,83 & 95,00 & 0,86 \\
\hline
\end{tabular}

Berdasarkan hasil analisis deskriptif pada Tabel 2, diperoleh nilai rata-rata peningkatan kemampuan pemahaman matematis siswa kelas eksperimen sebesar 0,6703. Nilai ini dapat dilihat dari interpretasi koefisien $N$-Gain yang menyatakan bahwa klasifikasi nilai koefisien $0,30 \leq \mathrm{g} \leq$ 0,70 berada dalam kategori sedang, (Jahring \& Marniati, 2020). Rata- rata peningkatan kemampuan pemahaman matematis siswa pada kelas kontrol sebesar 0.5449 juga termasuk dalam kategori sedang.

Tabel 3. Hasil analisis kemampuan pemahaman matematis siswa berdasarkan indikator.

\begin{tabular}{|c|c|c|c|}
\hline No & Indikator & Desain & Mean \\
\hline \multirow{2}{*}{1} & \multirow{2}{*}{ Translasi } & Pretest & 17,386 \\
\hline & & Posttest & 37,348 \\
\hline \multirow{2}{*}{2} & \multirow{2}{*}{ Interpolasi } & Pretest & 25 \\
\hline & & Posttest & 30,227 \\
\hline \multirow{2}{*}{3} & \multirow{2}{*}{ Ekstrapolasi } & Pretest & 10,340 \\
\hline & & Posttest & 12,545 \\
\hline
\end{tabular}

Perbandingan rata-rata setiap aspek kemampuan pemahaman matematis untuk kelas VIII sebelum diterapkan perlakuan (pretest) dan setelah diterapkan perlakuan (posttest) disajikan pada Tabel 3.

Selanjutnya dilakukan uji signifikansi peningkatan kemampuan pemahaman matematis siswa pada kelas eksperimen. Adapun hipotesis yang diuji didefinisikan sebagai berikut.

$$
H_{0}: \mu_{1} \leq 0 \text { lawan } H_{1}: \mu_{1}>0
$$

Keterangan:

$$
\begin{aligned}
& \mu_{1} \text { : Parameter rerata peningkatan } \\
& \text { kemampuan pemahaman } \\
& \text { matematis siswa }
\end{aligned}
$$

Hasil analisis uji-t tunggal terhadap signifikansi peningkatan kemampuan pemahaman matematis siswa pada kelas eksperimen dapat dilihat pada Tabel 4.

Tabel 4. Uji signifikansi peningkatan kemampuan pemahaman matematis siswa pada kelas eksperimen.

\begin{tabular}{ccccc}
\hline Model & $\boldsymbol{N}$ & $\boldsymbol{X}_{\boldsymbol{I}}$ & $\boldsymbol{t}$ & $\boldsymbol{H}_{\boldsymbol{0}}$ \\
\hline $\begin{array}{c}\text { STAD } \\
\text { dengan }\end{array}$ & & & & \\
$\begin{array}{c}\text { Pendekatan } \\
\text { RME }\end{array}$ & 26 & 0,6703 & 16,595 & Tolak \\
\hline
\end{tabular}


DOI: https://doi.org/10.24127/ajpm.v9i4.2979

Berdasarkan Tabel 4, diperoleh nilai $t_{\text {hitung }}=16,595>t_{\text {tabel }}=2,059$ yang berarti $H_{0}$ ditolak. Dengan demikian, terdapat peningkatan kemampuan pemahaman matematis siswa setelah diterapkan model pembelajaran kooperatif tipe STAD dengan pendekatan RME.

Selanjutnya, hasil analisis uji-t tunggal terhadap signifikansi peningkatan kemampuan pemahaman matematis siswa pada kelas kontrol disajikan pada Tabel 5 .

Tabel 5. Uji signifikansi peningkatan kemampuan pemahaman matematis siswa kelas kontrol.

\begin{tabular}{ccccc}
\hline Model & $\boldsymbol{N}$ & $\boldsymbol{X}_{\boldsymbol{I}}$ & $\boldsymbol{t}$ & $\boldsymbol{H}_{\boldsymbol{0}}$ \\
\hline Konvensional & 29 & 0,5449 & 14,653 & Tolak \\
\hline
\end{tabular}

Berdasarkan Tabel 5, diperoleh nilai thitung $=14,653>t_{\text {tabel }}=2,048$, yang berarti $H_{0}$ ditolak. Dengan demikian, terdapat peningkatan kemampuan pemahaman matematis siswa setelah penerapan pembelajaran konvensional.

Selanjutnya dilakukan uji perbedaan kemampuan matematis siswa antara kelas eksperimen dan kelas kontrol. Adapun hipotesis yang diuji didefinisikan sebagai berikut.

$$
H_{0}: \mu_{1} \leq \mu_{2} \text { lawan } H_{1}: \mu_{1}>\mu_{2}
$$

Keterangan:

$$
\begin{aligned}
\mu_{1}: & \begin{array}{l}
\text { Parameter rerata peningkatan } \\
\text { kemampuan }
\end{array} \\
& \begin{array}{l}
\text { pemahaman } \\
\text { matematis siswa pada kelas } \\
\text { eksperimen. }
\end{array}
\end{aligned}
$$

$\mu_{2}$ : Parameter rerata peningkatan kemampuan pemahaman matematis siswa pada kelas kontrol.

$$
\text { Hasil analisis perbedaan }
$$
kemampuan matematis siswa antara kelas eksperimen dengan kelas kontrol disajikan pada Tabel 6 .
Tabel 6. Uji signifikansi perbedaan ratarata peningkatan kemampuan pemahaman matematis siswa.

\begin{tabular}{ccccl}
\hline \multirow{2}{*}{$\boldsymbol{N}$-Gain } & $\boldsymbol{t}_{\text {hitung }}$ & $\boldsymbol{t}_{\text {tabel }}$ & df & $\boldsymbol{H}_{\boldsymbol{0}}$ \\
\cline { 2 - 5 } & 2,28 & 2.006 & 53 & Tolak \\
\hline
\end{tabular}

Berdasarkan Tabel 6, diperoleh nilai $t_{\text {hitung }}=2,28>t_{\text {tabel }}=2,006$, yang berarti $H_{0}$ ditolak dan $H_{1}$ diterima. Dengan ditolaknya $H_{0}$ dapat disimpulkan bahwa rata-rata peningkatan kemampuan pemahaman matematis siswa pada kelas eksperimen lebih tinggi daripada rata-rata peningkatan kemampuan pemahaman matematis siswa pada kelas kontrol.

Berdasarkan hasil penelitian yang telah diperoleh menunjukkan bahwa model pembelajaran kooperatif tipe STAD dengan pendekatan RME lebih efektif daripada model pembelajaran konvensional dalam meningkatkan kemampuan pemahaman matematis siswa Hal ini dilihat dari hasil analisis deskriptif menunjukkan bahwa hasil kemampuan awal siswa (Pretest) pada kelas eksperimen yang terdiri dari 26 siswa diperoleh nilai ratarata 53,365; standar deviasi 9,539; varians 90,99; nilai maksimum 75 dan nilai minimum 41,67. Sedangkan hasil pretest pada kelas kontrol yang terdiri dari 29 siswa diperoleh rata- rata 52,083; standar deviasi 9,579; varians 91,766; nilai maksimum 70,83 dan nilai minimum 37,5. Dari hasil pretest menunjukkan bahwa rata- rata kemampuan awal siswa berada dibawah nilai Kriteria Ketuntasan Minimal (KKM).

Berdasarkan hasil kemampuan pemahaman matematis siswa (Posttest) pada kelas eksperimen yang terdiri dari 26 siswa diperoleh nilai rata- rata 84,134; standar deviasi 10,098; varians 101,971; nilai maksimum 100 dan nilai 
minimum sebesar 62,5. Sedangkan hasil Posttest pada kelas kontrol yang terdiri dari 29 siswa, diperoleh nilai rata- rata 77,672; standar deviasi 11,494; varians 132,112; nilai maksimum 95 dan nilai minimum 57,5. Dari hasil posttest menunjukkan bahwa hasil kemampuan pemahaman matematis siswa pada kelas eksperimen dengan penerapan model pembelajaran kooperatif tipe STAD dengan pendekatan RME maupun pada kelas kontrol dengan penerapan pembelajaran konvensional telah mengalami peningkatan dan mencapai nilai KKM sekolah.

Selanjutnya ditinjau dari peningkatan kemampuan pemahaman matematis siswa pada kelas eksperimen dengan penerapan model pembelajaran kooperatif tipe STAD dengan pendekatan RME diperoleh nilai ratarata sebesar 0.6703; standar deviasi 0.206; varians 0.042. Sedangkan peningkatan kemampuan pemahaman matematis matematis siswa pada kelas kontrol dengan penerapan pembelajaran konvensional diperoleh nilai rata-rata 0.5449; standar deviasi 0.2003; varians 0.040. Berdasarkan hasil analisis ini, menunjukkan bahwa rata-rata peningkatan kemampuan pemahaman matematis siswa pada kelas eksperimen dan kemampuan pemahaman matematis siswa pada kelas kontrol tampak berbeda.

Dari hasil di atas, selanjutnya dilakukan pengujian hipotesis menggunakan uji-t pada taraf signifikansi $\alpha=0,05$ diperoleh nilai $t_{\text {hitung }}=2,287>t_{\text {tabel }}=2,006$. Hal ini berarti bahwa terdapat perbedaan yang signifikan dari peningkatan kemampuan matematis siswa pada kelas eksperimen dan kelas kontrol.

Uraian di atas sejalan dengan hasil penelitian yang dilakukan oleh (Surtiani \& Syahputra, 2016; Yulianty,
2019) tentang Model Pembelajaran Kooperatif tipe Student Teams Achievement Divisions (STAD) dan pendekatan Realistic Mathematic Education (RME). Dimana model pembelajaran STAD dan pendekatan pembelajaran RME sangat cocok dipadukan dalam melaksanakan pembelajaran di kelas, sebab dapat meningkatkan kemampuan matematis dan hasil belajar siswa. Lebih lanjut (Jarmita, 2012) menyatakan bahwa proses pembelajaran dengan menggunakan model pembelajaran kooperatif tipe STAD itu sendiri dapat meningkatkan pemahaman konsep matematis siswa. Dengan demikian bahwa model pembelajaran kooperatif tipe STAD dengan pendekatan RME lebih efektif dibandingkan dengan model pembelajaran konvensional terhadap kemampuan pemahaman matematis siswa kelas VIII MTs Nurul Yaqin Dawi-dawi.

\section{KESIMPULAN DAN SARAN}

Model pembelajaran Kooperatif tipe STAD dengan pendekatan RME lebih efektif jika dibandingkan dengan pembelajaran konvensional dalam meningkatkan kemampuan pemahaman matematis siswa kelas VIII MTs Nurul Yaqin Dawi-dawi. Hasil penelitian ini dapat dijadikan sebagai bahan referensi bagi guru dalam melaksanakan proses pembelajaran di kelas dan dapat pula dijadikan sebagai bahan rujukan bagi peneliti untuk penelitian selanjutnya dalam meningkatkan pemahaman konsep belajar matematika siswa.

\section{DAFTAR PUSTAKA}

Djidu, H., \& Jailani, J. (2017). Aktivitas Pembelajaran Matematika yang Dapat Melatih Kemampuan Berpikir Tingkat Tinggi Siswa. Prisma Prosiding Seminar Nasional Matematika, 312-321. 
DOI: https://doi.org/10.24127/ajpm.v9i4.2979

Jahring, J. (2020). Kemampuan Koneksi Matematis Pada Model Pembelajaran Connecting, Organizing, Reflecting, Extending dan Numbered Head Together. Aksioma: Jurnal Program Studi Pendidikan Matematika, 9(1), 182-189.

https://doi.org/10.24127/ajpm.v9i1. 2667

Jahring, J., \& Chairuddin, C. (2019). Preferensi Modalitas Belajar Mahasiswa Angkatan 2016 Program Studi Pendidikan Matematika Universitas Sembilanbelas November Kolaka. Square: Journal of Mathematics and Mathematics Education, 1(1), 27-32.

https://doi.org/10.21580/square.v1i 1.4039

Jahring, J., \& Marniati, M. (2020). Efektivitas Model Pembelajaran Inside Outside Circle (IOC) Terhadap Hasil Belajar Matematika Siswa SMP. Jurnal Karya Pendidikan Matematika, 7(1), 22-26. https://doi.org/10.26714/jkpm.7.1. 2020.22-26

Jailani, J., Sugiman, S., Retnawati, H., Bukhori, Apino, E., Djidu, H., \& Arifin, Z. (2018). Desain Pembelajaran Matematika Untuk Melatihkan Higher Order Thinking Skills. UNY Press.

Jarmita, N. (2012). Penerapan Pembelajaran Kooperatif Tipe Stad Dalam Meningkatkan Pemahaman Matematis Siswa Pada Pokok Bahasan Bangun Ruang. Jurnal Ilmiah Didaktika, 13(1), 150-172. https://doi.org/10.22373/jid.v13i1. 470

Mariamah, M. (2014). Penerapan Pembelajaran Kooperatif Numbered Head Together (NHT) untuk Meningkatkan Kemampuan Koneksi Matematika Siswa Kelas VIII SMP IT Suhadah Yogyakarta. Jurnal Pengkajian Ilmu Dan Pembelajaran Matematika Dan IPA “Prisma Sains," 2(1), 83-89. https://doi.org/https://doi.org/10.33 394/j-ps.v2i1.1058

Nasruddin, N., \& Abidin, Z. (2017). Meningkatkan Hasil Belajar Matematika Melalui Model Pembelajaran Kooperatif Tipe Jigsaw pada Siswa SMP. Journal of Educational Science and Technology, 3(2), 113-121. https://doi.org/https://doi.org/10.26 858/est.v3i2.3557

Nasruddin, N., Mashuri, S., \& Jahring, J. (2019). Implementation of Team Assited Individualization Instructional Strategies Supported by Geogebra Software to Improve Mathematical Problem Solving Ability. Jurnal Pendidikan Progresif, 9(1), 16-21. https://doi.org/10.23960/jpp.v9.i1. 201903

Nasruddin, N., Mashuri, S., \& Nafiah, U. (2020). Peningkatan Hasil Belajar Matematika pada Materi Segitiga Melalui Pendekatan Penemuan Terbimbing Siswa SMP. Jurnal Penelitian Dan Pengkajian Pendidikan: ESaintika, 4(2), 80-94. https://doi.org/https://doi.org/10.36 312/e-saintika.v4i2.169

Saputra, I. G. P., \& Sukariasih, L. (2019). Penerapan Creative Problem Solving dalam Peningkatan Kemampuan Berpikir Kritis Fisika Peserta Didik Kelas XI-IPA3 SMAN 1 Watubangga. Jurnal Pendidikan Fisika Tadulako Online (JPFT), 7(3), 16-21. 
Sejati, A. E., Amaluddin, L. O., Hidayati, D. N., Kasmiati, S., Sumarmi, S., \& Ruja, I. N. (2017). The Effect of Outdoor Study on the Geography Scientific Paper Writing Ability to Construct Student Character in Senior High School. Proceedings of the 5th SEA-DR (South East Asia Development Research) International Conference 2017 (SEADRIC 2017), 100, 104-108. https://doi.org/https://doi.org/10.29 91/seadric-17.2017.22

Suandito, B. (2017). Bukti Informal dalam Pembelajaran Matematika. Al-Jabar: Jurnal Pendidikan Matematika, 8(1), 13-24. https://doi.org/https://doi.org/10.24 042/ajpm.v8i1.1160
Surtiani, S., \& Syahputra, E. (2016). Penerapan Model Pembelajaran Kooperatif Tipe Student Teams Achievement Divisions (STAD) untuk Meningkatkan Pemahaman Konsep Persamaan Kuadrat di Kelas VIII SMP Negeri 3 Perbaungan. Inspiratif: Jurnal Pendidikan Matematika, 2(1), 92101. https://doi.org/https://doi.org/10.24 114/jpmi.v2i1.8936

Yulianty, N. (2019). Kemampuan Pemahaman Konsep Matematika Siswa Dengan Pendekatan Pembelajaran Matematika Realistik. Jurnal Pendidikan Matematika Raflesia, 04(01), 6065.

https://doi.org/https://doi.org/10.33 449/jpmr.v4i1.7530 